\title{
Rectal organ culture as a model for the investigation of bacterial adhesion and invasion
}

\author{
RJ DICKINSON, WJ BRANCH, RE WARREN, G NEALE \\ From the Department of Medical Gastroenterology and the Clinical Microbiology Laboratory, \\ Addenbrooke's Hospital, Cambridge, and the MRC Dunn Clinical Nutrition Centre, Cambridge
}

SUMMARY A system was developed for the in vitro culture of human rectal mucosa. Its viability was proved by histological appearances and by metabolic studies. Biopsy samples were cultured in the presence of appropriate bacteria isolated from the faeces of patients with ulcerative colitis or with dysenteric illnesses. Attempts to show adhesion of bacteria to the mucosa or invasion of the cultured tissue failed. Problems with the use of this model are discussed.

The ability of bacteria to adhere to or to invade host epithelia are of major importance in the pathogenesis of enteric infection. ${ }^{12}$ These properties have been assessed in vitro using HeLa and Hep 2 cell monolayers and suspensions of fetal colonocytes. ${ }^{3-5}$ The invasion of isolated cells by Escherichia coli and other pathogens correlates with in vivo properties, but the importance of bacterial adhesion to isolated cells remains unclear because bacterial strains showing in vitro adhesion do not necessarily possess other properties associated with pathogenicity. ${ }^{1-10}$ In view of these doubts and the probable complexity of host-parasite interactions in vivo we have investigated the ability of bacteria with known properties in the HeLa monolayers to adhere to or to invade biopsy samples of rectal mucosa maintained in organ culture.

\section{Material and methods}

Two rectal biopsy samples were obtained with standard forceps from outpatients undergoing sigmoidoscopy for the investigation of irritable bowel syndrome or for the management of ulcerative colitis. Each patient gave informed consent to the study, which had been approved by the appropriate ethical committee. One sample from each patient was processed routinely for histological examination and the other was placed immediately in culture medium for transport to the laboratory at ambient temperature. The samples were subsequently washed with fresh medium and divided into 1-2 mm

Accepted for publication 11 January 1984 squares with a scalpel. Two to three explants were obtained from the average sample.

\section{ORGAN CULTURE SYSTEM}

Each explant was orientated mucosa-side up in a peripheral area of a $6 \mathrm{~cm}$ plastic Petri dish, which had been abraded to encourage adherence. A maximum of two explants were mounted in each dish and $4 \mathrm{ml}$ of culture medium was added. The culture medium was that used by Defries and Franks ${ }^{12}$ as modified by Autrup et al..$^{13}$ Waymouth's MB 752/1 medium was supplemented with $10 \%$ fetal calf serum, hydrocortisone sodium succinate $(1 \mu \mathrm{g} / \mathrm{ml})$, ascorbic acid $(300 \mu \mathrm{g} / \mathrm{ml})$, ferrous sulphate $(0.45 \mu \mathrm{g} / \mathrm{ml})$, and $20 \mathrm{mM}$ tricene buffer $(\mathrm{pH}$ $7 \cdot 4$ ). The $\mathrm{pH}$ of the medium was adjusted to $7 \cdot 4$ with $1 \mathrm{M} \mathrm{NaOH}$. In control cultures (no bacteria to be added) the medium was supplemented with benzyl penicillin $(100 \mathrm{U} / \mathrm{ml})$, streptomycin $(100 \mu \mathrm{g} / \mathrm{ml})$, $\mathrm{ml})$, gentamicin $(50 \mu \mathrm{g} / \mathrm{ml}))$, and amphotericin B $(0.25 \mu \mathrm{g} / \mathrm{ml})$. Organ cultures were maintained in an atmosphere of $95 \% \mathrm{O}_{2}, 5 \% \mathrm{CO}_{2}$, at $37^{\circ} \mathrm{C}$ in a rocking chamber. Mucosal viability was assessed against cultures maintained in an atmosphere of $100 \% \mathrm{CO}_{2}$ or in air by histological examination and by the incorporation of ${ }^{14} \mathrm{C}$-leucine.

\section{ASSESSMENT OF VIABILITY \\ Histological studies}

Randomly selected explants were removed from culture at intervals of $3,6,12$, and $18 \mathrm{~h}$, fixed in buffered formal ( $\mathrm{pH} 7 \cdot 4$ ), routinely processed, and stained with haematoxylin and eosin for examination under the light microscope. 


\section{Incorporation studies}

At the start of culture $200 \mu \mathrm{L}-\left(\mathrm{U}-{ }^{14} \mathrm{C}\right)$ - leucine (Radiochemical Centre, Amersham) was added to each dish. Explants were removed at intervals of $2^{1 / 2}, 5,8,12$, and $18 \mathrm{~h}$ and washed in Waymouth's MB 752/1 medium containing $10 \mathrm{mM} \mathrm{N}$-acetyl cysteine (Airbron, Duncan Flockhart) to remove surface mucus. Each explant was homogenised manually in a Potter homogeniser in $1 \mathrm{ml} 1 \mathrm{M} \mathrm{NaCl}$. One millilitre of $10 \%$ trichloroacetic acid (TCA) was added to each homogenate and allowed to stand for 10 min or overnight at $4^{\circ} \mathrm{C}$. The homogenates were centrifuged at $3000 \mathrm{rpm}$ for $10 \mathrm{~min}$ and the supernatant was removed. The pellets were resuspended in 5\% TCA and recentrifuged before solubilisation of protein in $1 \mathrm{ml} 0.1 \mathrm{M} \mathrm{NaOH}$. Aliquots $(0.2 \mathrm{ml})$ of each preparation were added to $10 \mathrm{ml}$ scintillation fluid (Instagel-Packard Instruments) and counted for $10 \mathrm{~min}$ in a Phillips PW 450 liquid scintillation counter. Radioactive decay, as disintegrations per minute (dpm), was calculated by using $10 \mu \mathrm{l}$ of ${ }^{14} \mathrm{C}$ toluene of known specific activity as an internal standard. The remaining $0.8 \mathrm{ml}$ of solubilised protein was analysed for protein content by Lowry's method using bovine serum albumin as a standard. ${ }^{14}$ The results for each explant were recorded as dpm/ $\mu \mathrm{g}$ protein.

\section{EXPERIMENTS WITH ORGAN CULTURE AND BACTERIA \\ Bacterial strains}

$E$ coli strains with known properties in $\mathrm{HeLa}$ cell monolayers were used. All had been shown to be non-enterotoxigenic in $\mathrm{Y}_{1}$ adrenal cell and suckling mouse assays. ${ }^{111516}$ The strains and their properties on HeLa cell monolayers were as follows: $E$ coli 021:H47 (invasive), 01:H7 (adhesive), 064: H(adhesive), 01: H? (adhesive), 08: H- (nonadhesive/non-invasive), 01:H? (non-adhesive/noninvasive). In addition, $E$ coli strains SC13 (01:H7 non-invasive CFAI-/CFA II-) and E12860/0 ( $E$ coli 024:H-invasive) and one each of strains of Campylobacter jejuni and Shigella sonnei isolated from patients with diarrhoea were also investigated. The two reference $E$ coli strains were kindly provided by Dr B Rowe (Central Public Health Laboratories, Colindale). All the strains were stored on Dorset egg medium in the dark until use.

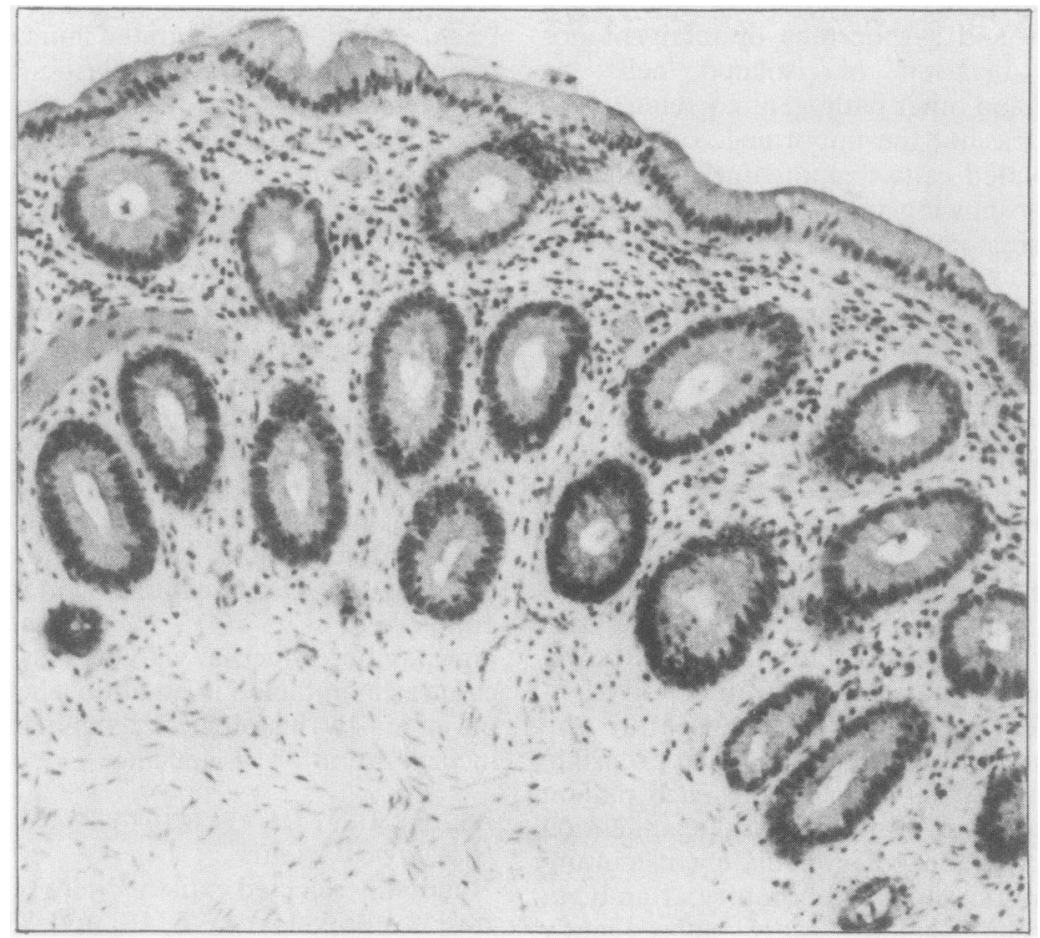

Fig. 1 Organ culture of rectal mucosa from a patient with the irritable bowel syndrome after $6 \mathrm{~h}$ incubation in test conditions.

Haematoxylin and eosin. Original magnification $\times 100$. 


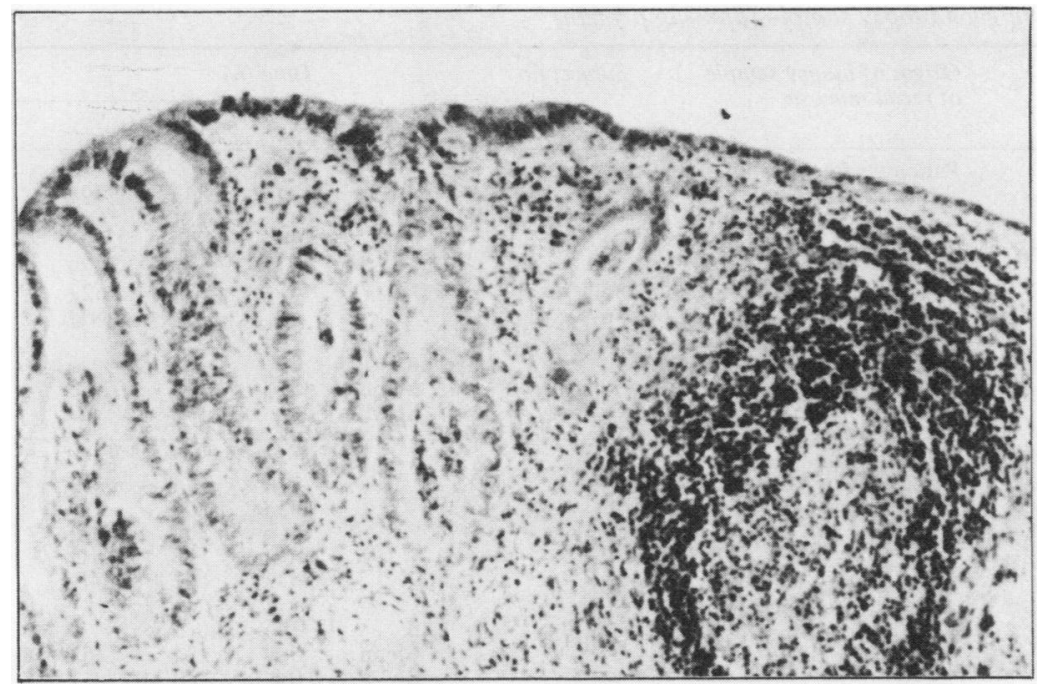

Fig. 2 Organ culture from a patient with ulcerative colitis after $18 \mathrm{~h}$ incubation in test conditions. Haematoxylin and eosin. Original magnification $\times 100$. There is epithelial attenuation and degeneration of the crypt bases but the overall architecture is preserved.

\section{Infection experiments}

Bacteria for each experiment were prepared from overnight peptone water cultures. They were centrifuged, washed, and resuspended in antibiotic free culture medium immediately before use. The concentration of the bacteria was estimated on the assumption that an overnight culture comprises $10^{8}$ bacteria/ml and were diluted accordingly to yield suspensions of about $10^{6}, 10^{7}$, and $10^{8} / \mathrm{ml}$. Each test and reference strain were tested at least twice in separate experiments.

The rectal biopsy samples for the infection experiments were kept in medium containing antibiotics for at least $1 \mathrm{~h}$. They were then washed three times with $4 \mathrm{ml}$ aliquots of phosphate buffered saline (PBS) and once with $4 \mathrm{ml}$ of fresh medium containing no antibiotics. They were then mounted in plastic Petri dishes directly on to abraded areas and orientated mucosa side up with forceps or a fine needle. Antibiotic free culture medium $(4 \mathrm{ml})$ was then added containing either $10^{6}, 10^{7}$, or $10^{8}$ bacteria $/ \mathrm{ml}$ and the cultures were incubated at $37^{\circ} \mathrm{C}$ as previously described. After varying intervals of culture $(1,3$, or $6 \mathrm{~h})$ they were washed three times with $4 \mathrm{ml}$ aliquots of fresh medium at room temperature to remove proliferating non-adherent bacteria and reincubated at $37^{\circ} \mathrm{C}$. After 3,6 , and $18 \mathrm{~h}$ of incubation the organ cultures were wahed three times with $4 \mathrm{ml}$ aliquots of PBS and fixed in phosphate buffered formalin.

Some variations to the technique were applied. Some organ cultures were mounted on to fibrin clots or blobs of clear agar in an attempt to prevent bacteria entering subepithelial tissues. This was technically more difficult and did not appear to encourage epithelial adhesion or invasion. In a few instances the reference invasive $E$ coli strain was added in saline solution and the biopsy samples were fixed after one hour, and in other instances the culture medium was further supplemented with $20 \mathrm{mM}$ sodium salicylate and $10 \mathrm{mM} \mathrm{N}$-acetyl-cysteine in an attempt to reduce and degrade surface mucus. ${ }^{17} 18$ These variations were applied in case the medium contained molecules which were blocking receptor sites for bacteria and in case the large amounts of mucus produced by the organ cultures mitigated against the success of the system. As a final modification the organ cultures were centrifuged with the infected culture medium for $30 \mathrm{~min}$ at $2000 \mathrm{rpm}$ before incubation. This was attempted in order to encourage contact between the test bacteria and the epithelial surface of the organ cultures.

\section{Results}

ASSESSMENT OF VIABILITY OF ORGAN CULTURES Histological studies

Biopsy samples were taken both from intact mucosa of five patients with ulcerative colitis with inactive or moderately active disease activity and from six patients with normal rectal mucosa in whom a clinical diagnosis of the irritable bowel syndrome was made. 
${ }^{14} \mathrm{C}$ incorporation in each biopsy sample (dpm/ $\mu \mathrm{g}$ protein)

\begin{tabular}{|c|c|c|c|c|c|c|c|c|}
\hline \multirow[t]{2}{*}{ Atmosphere } & \multirow{2}{*}{$\begin{array}{l}\text { Origin of biopsy sample } \\
\text { of rectal mucosa }\end{array}$} & \multirow[t]{2}{*}{ Subject no } & & \multicolumn{5}{|c|}{ Time (h) } \\
\hline & & & & 0 & $21 / 2$ & 5 & 8 & 18 \\
\hline \multirow[t]{5}{*}{$95 \% \mathrm{O}_{2} / 5 \% \mathrm{CO}_{2}$} & $\begin{array}{l}\text { Patients with irritable } \\
\text { bowel syndrome }\end{array}$ & $\begin{array}{l}1 \\
2 \\
3 \\
4 \\
5 \\
6\end{array}$ & & $\begin{array}{c}\text { ND } \\
\text { ND } \\
\text { ND } \\
\text { ND } \\
4 \\
5\end{array}$ & $\begin{array}{r}63 \\
131 \\
50 \\
\text { ND } \\
337 \\
\text { ND }\end{array}$ & $\begin{array}{l}499 \\
186 \\
198 \\
279 \\
627 \\
\text { ND }\end{array}$ & $\begin{array}{l}274 \\
215 \\
149 \\
349 \\
\text { ND } \\
193\end{array}$ & $\begin{array}{c}993 \\
589 \\
715 \\
616 \\
\text { ND } \\
488\end{array}$ \\
\hline & & & $\begin{array}{l}\mathbf{n} \\
\text { Mean } \\
\text { SEM }\end{array}$ & $\begin{array}{c}2 \\
45 \\
0 \cdot 5\end{array}$ & $\begin{array}{r}4 \\
145 \\
66\end{array}$ & $\begin{array}{r}5 \\
358 \\
88\end{array}$ & $\begin{array}{l}5 \\
236 \\
35\end{array}$ & $\begin{array}{r}5 \\
680 \\
81\end{array}$ \\
\hline & $\begin{array}{l}\text { Patients with ulcerative } \\
\text { colitis }\end{array}$ & $\begin{array}{r}7 \\
8 \\
9 \\
10 \\
11\end{array}$ & & $\begin{array}{c}7 \\
5 \\
4 \\
\text { ND } \\
\text { ND }\end{array}$ & $\begin{array}{r}174 \\
106 \\
69 \\
168 \\
102\end{array}$ & $\begin{array}{l}343 \\
213 \\
232 \\
\text { ND } \\
\text { ND }\end{array}$ & $\begin{array}{l}\text { ND } \\
\text { ND } \\
\text { ND } \\
360 \\
429\end{array}$ & $\begin{array}{r}819 \\
1108 \\
444 \\
1723 \\
862\end{array}$ \\
\hline & & & $\begin{array}{l}\mathrm{n} \\
\text { Mean } \\
\text { SEM }\end{array}$ & $\begin{array}{l}3 \\
5 \cdot 3 \\
0 \cdot 8\end{array}$ & $\begin{array}{c}5 \\
124 \\
20 \cdot 3\end{array}$ & $\begin{array}{r}3 \\
263 \\
41\end{array}$ & $\begin{array}{r}2 \\
395 \\
35\end{array}$ & $\begin{array}{r}5 \\
991 \\
212\end{array}$ \\
\hline & Combined results & & $\begin{array}{l}\text { n } \\
\text { Mean } \\
\text { SEM }\end{array}$ & $\begin{array}{l}5 \\
5 \\
0 \cdot 6\end{array}$ & $\begin{array}{r}99 \\
113 \\
29\end{array}$ & $\begin{array}{r}8 \\
322 \\
57\end{array}$ & $\begin{array}{r}7 \\
281 \\
39\end{array}$ & $\begin{array}{r}10 \\
836 \\
119\end{array}$ \\
\hline \multirow[t]{2}{*}{$100 \% \mathrm{CO}_{2}$} & $\begin{array}{l}\text { Patients with irritable } \\
\text { bowel syndrome }\end{array}$ & $\begin{array}{l}12 \\
13\end{array}$ & & $\begin{array}{l}\text { ND } \\
\text { ND }\end{array}$ & $\begin{array}{l}19 \\
12\end{array}$ & $\begin{array}{r}61 \\
9\end{array}$ & $\begin{array}{r}67 \\
9\end{array}$ & $\begin{array}{r}411 \\
12\end{array}$ \\
\hline & & & $\begin{array}{l}\text { n } \\
\text { Mean }\end{array}$ & $\underline{0}$ & $\begin{array}{c}2 \\
15 \cdot 5\end{array}$ & $\begin{array}{r}2 \\
35\end{array}$ & $\begin{array}{r}2 \\
38\end{array}$ & $\begin{array}{r}2 \\
212\end{array}$ \\
\hline
\end{tabular}

ND $=$ not done.

Organ cultures from either source were intact after incubation for $6 \mathrm{~h}$ in $95 \% \mathrm{O}_{2} 5 \% \mathrm{CO}_{2}$ (Fig. 1). At $18 \mathrm{~h}$ there was usually some attenuation of the surface epithelium and degeneration of the crypt bases (Fig. 2). In contrast, organ cultures incubated in air or $100 \% \mathrm{CO}_{2}$ showed cytolysis and epithelial destruction after culture for $6 \mathrm{~h}$.

\section{Metabolic studies}

The data are given in the Table. Biopsy samples of rectal mucosa derived both from control subjects with irritable bowel syndrome and from patients with ulcerative colitis continued to incorporate leucine into protein throughout the $18 \mathrm{~h}$ of incubation. Samples maintained in $100 \% \mathrm{CO}_{2}$ or in air did much less well. These results confirm that rectal biopsy samples from patients with ulcerative colitis are as viable in culture as those from "controls". ${ }^{19}$ The combined results show a linear incorporation of leucine into protein throughout the $18 \mathrm{~h}$ of culture $(y=44 \cdot 3 x+17, r=0.98, n=6)$.

\section{EXPERIMENTS WITH ORGAN CULTURE AND BACTERIA}

Fifty eight attempts were made to show a close relation between mucosal biopsy samples and proliferating bacteria in the culture system described above.
An intimate relation was seen in only one instance where $E$ coli (strain SC13) appeared to be invading the epithelium of rectal mucosa obtained from a patient with the irritable bowel syndrome. In all other cases epithelial adhesion or invasion was not evident, although bacteria were often seen in the subepithelial tissue, where the mucosa had been denuded of epithelium or in surface mucus. Variations in the incubation time and means of mounting of the samples and prior centrifugation appeared to make no difference, and when sodium salicylate and $\mathrm{N}$-acetyl-cysteine were added to the medium to try to reduce and degrade mucus this led to premature morphological demise of the organ cultures without evidence of bacterial adhesion or invasion of the epithelium. Similarly, when the bacteria were added in saline solution and the organ cultures were fixed after $1 \mathrm{~h}$ of incubation there was no evidence of bacterial adhesion or invasion.

\section{Discussion}

These results confirm previous findings that rectal mucosa from normal patients and from patients with ulcerative colitis can be maintained in organ culture for at least $18 \mathrm{~h} .^{1319}$ 
None of the bacterial strains tested, whether they were proven or putative pathogens was seen consistently to adhere to or invade the epithelium. Bacteria were seen in the deeper tissues but this is considered to be of doubtful pathological importance. Thus this technique cannot be used to show pathogenicity of suspected or proven large intestinal pathogens. At first sight this result is surprising because Candy et $a^{20}$ have successfully used jejunal biopsy samples in short term culture to show the adhesion of pathogenic $E$ coli. There are several possible explanations.

Organ cultures of the rectum, unlike the jejunum, produce large amounts of mucus which may have a protective role, ${ }^{621}$ but attempts to reduce the mucus barrier by the addition of sodium salicylate and $\mathrm{N}$-acetyl-cysteine to the medium were unsuccessful. Next, it is probable that bacterial adhesion to the colonic mucosa depends both on chemical attractants normally present in the intestine and on the presence of other indigenous bacteria to which the pathogenic strains might initially adhere. ${ }^{6}$ It is possible that the pretreatment of the organ cultures with antimicrobials mitigated against the use of this system. It is also possible that appropriate receptors for adhesion were not expressed on the organ cultures because of some constituents of the culture medium. Receptors on the cell surfaces which allow bacterial adhesion may, for example, be blocked by carbohydrates competing for the binding sites. ${ }^{622}$ But bacterial adhesion could not be shown in saline solutions either, and this is an unlikely single explanation for the failure of the model.

Thus we have failed to establish a role for organ cultures of rectal mucosa in the investigation of the action of pathogenic bacteria in the large intestine. We have established a culture system which is reliable and easy to maintain, but no pathogen, whether proven or putative, was found to damage consistently the mucosa of rectal biopsy samples. This failure is probably related to one or more factors which operate in vivo but not in vitro.

We thank Dr DGD Wight and B Disbrey for help with the histology and Professor EM Cooke, under whose direction and in whose laboratory the $E$ coli strains were investigated by one of us (RJD). We also thank the technical staff of the Clinical Microbiology Laboratory, Addenbrooke's Hospital, for their assistance. This study was supported in part by a grant to one of us (RJD) from the East Anglian Regional Health Authority.

\section{References}

' Evans N. Pathogenic mechanisms in bacterial diarrhoea. Clin Gastroenterol 1979;8:599-623.

${ }^{2}$ Anonymous. Microbial adhesion, colonisation, and virulence
(Editorial). Lancet 1981;ii:50́8-10.

${ }^{3}$ Hartley CL, Robbins CM, Richmond MH. Quantitative assessment of bacterial adhesion to eukaryotic cells of human origin. J Appl Bacteriol 1978;45:91-7.

4 Dickinson RJ, Varian SA, Axon ATR, Cooke EM. Increased incidence of faecal coliforms with in vitro adhesive and invasive properties in patients with ulcerative colitis. Gut 1980;21:787-92.

${ }^{5}$ McNeish AS, Fleming J, Turner P, Evans N. Mucosal adherence of human enteropathogenic Escherichia coli. Lancet 1975;ii:946-8.

- Freter R. Mechanisms of association of bacteria with mucosal surfaces. In: Adhesion and microorganism pathogenicity. Ciba Foundation Symposium No 80. Tunbridge Wells: Pitman Medical, 1981:36-45.

' Bergman MJ, Updike WS, Wood SJ, Brown SE, Guerrant RL. Attachment factors among enterotoxigenic Escherichia coli from patients with acute diarrhoea from diverse geographic areas. Infect Immun 1981;32:881-8.

${ }^{8}$ Sugarman B, Donta ST. Specificity of attachment of certain Enterobacteriaceae to mammalian cells. J Gen Microbiol 1979;115:509-12.

9 Gianella RA, Washington O, Gemski P, Formal SB. Invasion of Hela cells by Salmonella typhimurium: a model for the study of invasiveness of salmonella. J Infect Dis 1973;128:69-75.

${ }^{10}$ Mäki M, Grönroos P, Vesikavi T. In vitro invasiveness of versinia enterocolitica isolated from children with diarrhoea. $J$ Infect Dis 1978;138:677-80.

" Dickinson RJ. Enteric infection and ulcerative colitis. London: University of London, 1983. MD Thesis.

${ }^{12}$ Defries EA, Franks LM. An organ culture method for adult colon from germ free and conventional mice: effects of donor age and carcinogen treatment on epithelial mitotic activity. $J$ Natl Cancer Inst 1977;58:1323-8.

${ }^{13}$ Autrup H, Barrett LA, Jackson FE, et al. Explant culture of human colon. Gastroenterology 1978;74:1248-57.

${ }^{14}$ Lowry OH, Rosebrought NJ, Farr AL, Randall RJ. Protein measurement with the Folin phenol reagent. J Biol Chem 1951;193:265-75.

is Donta ST, Moon HW, Whipp SC. Detection of heat labile Escherichia coli enterotoxin with the use of adrenal cells in tissue culture. Science 1974;183:334-5.

16 Dean AG, Ching Y-C, Williams RG, Harden LB. Test for enterotoxin production using infant mice: application in a study of diarrhoea in children in Honolulu. $J$ Infect Dis 1972;125:407-11.

${ }^{17}$ Lukie BE, Forstner GG. Synthesis of intestinal glycoproteins. Inhibition of $\mathrm{I}^{-14} \mathrm{C}$ Glycosamine incorporation by sodium salicylate in vitro. Biochem Biophys Acta 1972;273:380-8.

${ }^{18}$ Gilman AG, Goodman LS, Gilman A. Goodman and Gilman's the pharmacological basis of therapeutics. 6th ed. New York: Macmillan, 1980:960.

${ }^{19}$ MacDermott RP, Donaldson RM, Trier JS. Glycoprotein synthesis and secretion by mucosal biopsies of rabbit colon and human rectum. $J$ Clin Invest 1974;54:545-54.

${ }^{20}$ Candy DCA, Leung TSM, Phillips AD, Harries JT, Marshall WC. Models for studying the adhesion of enterobacteria to the mucosa of human gastro-intestinal tract. In: Adhesion and microorganism pathogenicity. Ciba Foundation Symposium No 80. Tunbridge Wells: Pitman Medical, 1981:36-55.

${ }^{21}$ Florey HW. Observations on the functions of mucus and the early stages of bacterial invasion of the intestinal mucosa. Journal of Pathology and Bacteriology 1933;37:283-9.

${ }^{22}$ Ofek I, Mirelman D, Sharon N. Adherence of Escherichia coli to human mucosal cells mediated by mannose receptors. Nature 1977;265:623-5.

Requests for reprints to: Dr RJ Dickinson, Department of Medicine, Addenbrooke's Hospital, Hills Road, Cambridge CB2 2QQ. 